\title{
Toivo Pihlajaniemi
}

\section{Hajauta ja hallitse}

\begin{abstract}
Pihlajaniemi, Toivo 1986. Hajauta ja hallitse. Aikuiskasvatus 6, 2, 87-90. - Hallinnon hajauttamiskomitean (komiteanmietintö 1986:12) yhtenä sihteerinä toiminut kirjoittaja käsittelee artikkelissaan komitean työn lähtökohtia, tavoitteita ja ehdotuksia. Ehdotusten käsittelyssä keskitytään toisaalta hallintoa yleisesti koskeviin ja toisaalta opetus-ja aikuiskasvatushallintoa erityisesti koskeviin ehdotuksiin.
\end{abstract}

Valtioneuvosto asetti vuoden 1984 alussa kansliapäällikkö Aimo Pajusen johtaman komitean laatimaan selvitykset tehtävien ja toimivallan siirtämisestä keskushallinnosta alueja paikallishallintoon sekä keskusvirastojen tehtävistä ja asemasta. Komitean tuli valmistella ehdotukset

a. valtionhallinnon rakenteen uudistamiseksi ja tässä yhteydessä erityisesti keskusvirastojen ja muun ministeriöiden alaisen keskushallinnon tehtävien ja aseman kehittämiseksi sekä tätä hallintoa koskevaksi yleiseksi lainsäädännöksi,

b. tehtävien ja toimivallan siirtämiseksi keskusvirastoilta yhtäältä läänin- tai muulle valtion väliportaanhallinnolle ja paikallishallinnolle taikka kunnille ja toisaalta asianomaisille ministeriöille, sekä

c. erityisesti niinsanottujen hallinnollisten keskusvirastojen uudelleen järjestämiseksi, yhdistämiseksi tai lakkauttamiseksi sekä näiden ehdotusten toteuttamisen vaatimaksi lainsäädännöksi.

Komitea luovutti mietintönsä 29.4.1986.

\section{Miksi Hallinnon hajauttamis- komitea asetettiin?}

Komitean asettamispäätöksen perustelumuistiossa todettiin muun muassa:

"Suomen valtion keskushallinto on kehittynyt jo ennen itsenäisyytemme alkua kaksijakoiseksi. Tämä kansainvälisesti katsoen harvinainen hallinnon järjestämistapa on ajoittain ollut selvitysten ja uudistusehdotusten kohteena...
Aikaisemmin keskusvirastojen tarpeellisuutta keskushallinnon erillisenä hallinnon tasona epäiltiin ministeriöissä ja keskusvirastoissa tapahtuvan kaksinkertaisen työn vuoksi. Viime aikoina on kiinnitetty huomiota siihen, että keskusvirastojen käsiteltävinä on asioita, jotka luonteensa puolesta tulisi käsitellä valtion läänin tai muussa väliportaanhallinnossa ja paikallishallinnossa tai kunnallishallinnossa tai yhteiskunnallisen merkityksensä vuoksi ministeriötasolla...

Tehtävien ja toimivallan siirtäminen alaspäin hallinnossa on omaksuttu keskeiseksi valtionhallinnon kehittämisperiaatteeksi myös 1980-luvulla...

Tähän mennessä tehdyt selvitykset ovat johtaneet mainittaviin tuloksiin vain muutamissa tapauksissa. Syynä siirtojen niukkuuteen on ollut muun muassa selvitysten vaatima suuri työmäärä ja keskusvirastojen vastustus sekä se, että selvitysten laadinnan ja niiden tuloksena syntyneiden ehdotusten toteutuksen taustalla ei ole ollut riittävän korkealla päätöksenteko- ja normitasolla vahvistettua valtion keskushallinnon yleisen hierarkisen jaon säännöstöä...

Edellä esitetyistä syistä on tarpeen asettaa komitea selvittämään keskusvirastojärjestelmän asemaa. Komitean työllä voidaan vauhdittaa tehtävien ja toimivallan siirtoja keskusvirastoilta aluehallinnolle ja kunnille."

Komitean ehdotusten tavoitteena tuli olla hallinnon hajauttaminen sekä sen kokonaisorganisaation uudistaminen kansanvaltaista kontrolloitavuutta ja kansalaisläheisyyttä parantavalla tavalla. Erityisesti komitean piti selvittää "ministeriöhallinnosta erillisen keskusvirastojärjestelmän tarpeellisuus ja hallinnon eri tasojen välttämättömyys yleensäkin." 


\section{Hallinnon nykytila}

Komitea tarkasteli työnsä aluksi valtion ja julkisen hallinnon tehtävien ja toimivaltarakenteiden kehitystä ja totesi niissä tapahtuneen aikojen kuluessa merkittäviä muutoksia.

Oikeudellisen tehtävänsä ohella nykyaikaisilla valtioilla oli alunperinkin sisäisen järjestyksen ja ulkoisen turvallisutuden ylläpitoon liittyviä tehtäviä.

Teollisen vallankumouksen myötä ja siitä aiheutuvista seurausilmiöistä johtuen valtiot alkoivat ottaa suorittaakseen yhteiskunnallisen perusvarustuksen (infrastruktuurin) rakentamiseen ja ylläpitämiseen liittyviä tehtäviä sekä taloudellisten toimintojen häiriöistä johtuvien sosiaalisten ongelmien lievittämiseen tähtääviä tehtäviä.

Erityisesti toisen maailmansodan jälkeisessä tehtäväkehityksessä on ollut näkyvissä sekä tehtävien edelleen laajentumista että varsin selviä painotusmuutoksia. Kehitys on merkinnyt siirtymistä perinteisistä järjestys- ja turvallisuustehtävistä sekä yhteiskunnallisen infrastruktuurin rakentamisesta entistä suuremmassa määrin hyvinvointi- ja taloudellisiin tehtäviin.

Valtiollisen tehtäväalueen laajentuminen ja siinä tapahtuneet painoaluemuutokset ovat merkinneet valtioroolin aktivoitumista. Valtion suhde kansalaisiin ja muuhun yhteiskuntaelämään on muuttunut. Valtiovalta toteuttaa tarkoituksiaan ja sääntelee tehtäviään aikaisempaa useammanlaisilla ohjausmenetelmillä.

Valtiovallan käyttämistä ohjausmenetelmistä vanhin on tapauskohtainen päätöksenteko (in casu hallitseminen). Ohjausmenetelmien kehityksen seuraava aste oli normiohjeinen päätöksentekomenettely (lainsäädäntö). Viime vuosikymmeninä on pyritty kehittelemään normiohjaustakin laaja-alaisempia ohjaamisen menetelmiä. Se on tapahtunut systematisoimalla budjettimenettelyä sekä kehittämällä laajoja suunnittelujärjestelmiä.

Valtiosäännöllä säännelty valtiojärjestyksemme perustuu edustukselliseen kansanvaltaan sekä ylimmän valtiovallan jakoon lainsäädäntövaltaan, toimeenpanovaltaan ja tuomiovaltaan.

Ylimpien valtioelinten ja hallinto-organisaation keskinäissuhde rakentuu toimeenpanovallan lojaliteetin periaatteelle.

Hallinto-organisaation sisainen rakenne noudattaa byrokraattista organisaatiomallia.

Suomessa ei ole ministeriöiden alaisen hallinnon hierarkista rakennetta ja toimivallanja- koa koskevaa yleislainsäädäntöä. $\mathrm{Ne}$ ovat muovautunueet hallinnonaloja ja hallintoyksiköitä koskevien aineellisten ja organisatoristen erityislakien ja alemmanasteisten normien pohjalta. Tällainen tilanne on ollut aiheuttamassa tai ainakin tekemässä osaltaan mahdolliseksi mm. seuraavia julkisen vallan ja kansalaisten vuorovaikutussuhteelle kielteisiä kehityksen kulkuja:

- Valtiovallan käytön painopiste on siirtynyt ylemmiltä valtioelimiltä entistä enemmän hallintoviranomaisille.

- Hallinto-organisation sisällä kehitys on ollut keskushallintopainotteista.

Keskushallinnon sisällä painopiste on siirtynyt ministeriöistä keskusvirastojen suuntaan.

- Kunnallishallintokin on tullut entistä enemmän valtionhallinnolle alistetuksi sekä joutunut siirtymään yhä suuremmassa määrin kuntainliitoiksi järjestettyyn välilliseen itsehallintoon.

- Monimuotoistaessaan ja aktivoidessaan kansalaisiin vaikuttavia toimintojaan valtiovalta on liukunut itse kansalaisten kannalta yhä moniportaisempien ja ohuempien vaikutusmahdollisuuksien päähän.

Mitä tulee komitean erityisen huolen kohteeksi asetettuun keskusvirastojärjestelmään, komitea saattoi havaita siihen kytkeytyneen seuraavia kehityspiirteitä:

- Ministeriöjärjestelmän ohella toimiva itsenäinen keskusvirastojärjestelmä ja sen vähittäinen laajentuminen on merkinnyt keskushallinnon virkamiesvaltaistumista ja "epäparlamentarisoitumista".

- Vallan ohella keskusvirastoihin on keskittynyt sellaista asiantuntemusta, jota saatettaisiin tarvita ministeriöissä.

- Niinikään keskusvirastoihin on kerääntynyt asioita, jotka voitaisiin käsitellä alue- ja paikallisella tasolla.

- Keskusvirastot ovat ottaneet itselleen sellaista norminantovaltaa, jota niillä parlamentaarisen demokratian periaatteiden mukaan ei pitäisi olla.

\section{Hajauttamisen tavoitteet}

Komitea asetettiin hajauttamaan hallintoa tarkoituksena sen kansalaisläheisyyden ja kansanvaltaisuuden parantaminen. Näiden varsinaisten tavoitteiden ohella hallinnon hajauttamisella on yhteyksiä myös muihin keskeisiin hallinnon kehittămistavoitteisiin. Hallintoa 
hajauttamalla voidaan siirtää sen toimintojen painopistettä hallitsemisnäkökulmasta palvelunäkökulman suuntaan. Oikealla tavalla hallintoa hajauttamalla saatetaan vähentää menettelyjen kankeutta ja monimutkaisuutta sekä lisätä niiden tuloksellisuutta ja tehokkuutta. Toimivallan siirtäminen alaspäin tekee mahdolliseksi muutoksenhakuasteiden lisäämisen ja näin sen kautta voidaan, jos niin halutaan, vahvistaa myös kansalaisten oikeusturvaa.

Hallinnon kansalaisläheisyyden parantamisen katsottiin edellyttävän toisaalta tehtävien ja toimivallan siirtämistä keskushallinnosta lähempänä kansalaisia toimiviin alue- ja paikallishallintoon sekä toisaalta alempien viranomaisten itsenäisyyden lisäämistä niiden hoitaessa nykyisiä ja tulevia tehtäviään. Kansanvaltaisuuden parantaminen vaatii puolestaan kansalaisia edustavien elinten, eduskunnan, valtioneuvoston ja ministeriöiden roolien tehostamista hallinto-organisaation yhteiskuntapoliittisessa ohjaamisessa.

Tehtävien ja toimivallan hajautuksen sekä hallinnon organisatiorakenteiden välillä on ensi silmäyksellä ehkä hieman paradoksaaliselta näyttävä suhde. Keskitettyyn hallintoon näyttää liittyvän hajanainen - hierarkisesti moniportainen ja sektoreittaisesti pirstoutunut organisaatio. Sen vuoksi hallinnon ja kansalaisten vuorovaikutusta voidaan tehostaa myös poistamalla turhimpia hierarkiatasoja ja tarpeettomimpia erillisyksiköitä.

\section{Yleiset ehdotukset}

Komitea katsoi, että keskushallinnon tehtäviä ja toimivaltaa tulee siirtää ensisijaisesti kuntiin. Lisäksi se totesi, että kunnille osoitettavien asioiden hoito pitää järjestää sillä tavalla, että kunnilla on niissä myös tosiasiallinen ratkaisuvalta, eikä valtiovalta harjoita niissä tarpeetonta resurssi- tai muutakaan toiminnallista ohjailua.

Komitean tehtävänä ei ollut käsitellä väliasteen hallinnon järjestämistapaa, eikä se sen vuoksi ottanut kantaa, millä tavoin sen alueelliselle tasolle siirrettäviksi ehdotettavien asioiden hoito pitäisi järjestää. Kuitenkin se katsoi, että läänin- ja piirihallintoa on kehitettävä pitäen silmällä niiden edellytyksiä keskushallinnosta siirrettävien tehtävien vastaanottamiseen.

Keskushallinnossa komitean mielestä on vahvistettava ministeriöhallinnon asemaa. Yhteiskuntapolitiikan sisältöön vaikuttavat rat- kaisut, joita ei tehdä eduskunnassa, tulee tehdä valtioneuvostossa ja ministeriöissä. Ministeriöiden alaisten keskushallinnon yksiköiden roolina tulee olla ylempiä valtioelimiä ja ministeriöitä sekä alue- ja paikallishallintoa avustavina erityisasiantuntijayksikköinä toimiminen. Hallinnollista päätöksentekoa on siirrettävä keskushallinnon virastoista voimakkaasti hallinnon alemmille tasoille sekä hallinnollisia ohjaustehtäviä ja toimivaltaa ministeriöihin. Kun keskushallinnon virastojen tehtävät tulevat näin määrällisesti vähenemään, voidaan toisiaan lähellä olevia tehtäviä hoitavia yksiköitä yhdistää.

Komitea katsoi erityisen tarkastelunsa kohteeksi ottamistaan virastoista erityisen "mielenkiintoisiksi"' ne, jotka harjoittavat ns. hyvinvointipalvelujen ohjausta. Näiltä osin komitea päätyi ehdottamaan kehityksen suuntaamista kohti uudenlaista virastotyyppiä, jota se päätti kutsua kehittämiskeskukseksi. Kehittämiskeskus olisi toiminta-ajatukseltaan asiantuntijaviranomainen, jonka tehtävänä olisi sektorinsa valtakunnallinen kehittäminen sekä palvelujen ja muiden toimintojen laadullinen ohjaaminen. Palvelujen laatua kehittämiskeskuksen pitäisi ohjata lähinnä neuvomalla, tiedottamalla ja kouluttamalla sekä avustamalla ministeriötä palveluja koskevan yhteiskuntapolitiikan valmistelussa.

Yksityiskohtaisissa ehdotuksissaan komitea päätyi esittämään nykyisistä lääkintö- ja sosiaalihallituksesta muodostettavan sosiaali- ja terveydenhuollon kehittämiskeskuksen sekä nykyisistä ammattikasvatushallituksesta ja kouluhallituksesta muodostettavan koulutuksen kehittämiskeskuksen perustamista. Seuraavassa muutamia toteamuksia jälkimmäisestä ehdotuksesta.

\section{Ammattikasvatushallitus ja kouluhallitus $\rightarrow$ koulutuksen kehittämiskeskus}

Komitea esittää ammattikasvatushallituksessa ja kouluhallituksessa tapahtuvan tapauskohtaisen päätöksenteon siirtämistä pääosiltaan oppilaitoksille, kunnallishallinnolle ja lääninhallituksille sekä tätä päätöksentekoa koskevien ohjaustehtävien osittaista siirtämistä opetusministeriöön. Ammattikasvatushallitus ja kouluhallitus tulee komitean esityksen mukaan yhdistää ja muodostaa niistä yhtenäinen koulutuksen kehittämiskeskus. 
Koulutuksen kehittämiskeskuksen keskeisenä tehtävänä tulisi komitean mukaan olemaan perus- ja keskiasteen koulutuksen sekä aikuiskoulutuksen valtakunnallinen kehittäminen sekä koulutuksen sisällöllinen ja pedagoginen ohjaaminen.

Hallinnollisina tehtävinä kehittämiskeskukselle jäisi peruskoulun, lukion ja ammatillisten oppilaitosten valtakunnallisista oppimääristä ja opetussuunnitelmista ym. koulutuksen samantasoisuudesta ja oppilaiden yhdenvertaisuudesta huolehtimiseen liittyvistä asioista päättäminen. Virastojen nykyisin harjoittamaa määräysten ja ohjeiden antamista uudistettaisiin muun muassa opetuksen järjestelyä koskevia normeja vähentämällä ja siirtymällä neuvontamenettelyyn.

Lääninhallitukset siirtyisivät opetustoimen hoitoon liittyvissä asioissa suoraan opetusministeriön alaisiksi, ellei joistakin tehtävistä säädettäisi erikseen toisin. Kehittämisasioissa lääninhallitukset olisivat yhteydessä kehittämiskeskukseen. Koulutuksen kehittämiskeskuksen johtoelimeksi tulisi johtokunta, jossa olisi valtioneuvoston nimeämiä asiantuntijajäseniä.

Komitean yhtenä, ja pääasiassa muita kuin opetustoimeen liittyviä erityisehdotuksia valmistelleena, sihteerinä tämän kirjoittaja ei ole sovelias eikä kompetenttikaan arvioimaan ehdotuksia ja varsinkaan niiden yksityiskohtia. Silti lienee paikallaan - tällä foorumilla kun ollaan - esittää joitakin yleishuomioita kou- lutoimen hallintoa koskevien esitysten vaikutuksista erityisesti aikuiskasvatusasioiden käsittelyyn.

Komitea totesi kouluhallinnossa, kuten hallinnon muillakin sektoreilla, käsiteltävän keskushallinnossa paljon sellaisia asioita, jotka voitaisiin käsitellä alemmilla hallinnon tasoilla. Lisäksi se totesi, että keskushallinto on kehittynyt keskusvirastopainotteisesti, ja että keskusvirastot ovat kehittyneet keskenään erilaisemmiksi kuin niiden hoitamien sektoreiden ominaispiirteet edellyttäisivät. Keskushallinnossa käsitellään aikuiskoulutusasioita nykyisin sekä kouluhallituksessa, ammattikasvatushallituksessa että opetusministeriön kouluosastossa. Kouluosaston asiat jakaantuvat vielä aikuiskoulutukseen suoraan kohdistuvaan ja välillisesti (kouluhallituksen ja ammattikasvatushallituksen kautta) kohdistuvaan hallintoon.

Komitean ehdotuksilla pyritään opetusministeriön ja sen kouluosaston roolien tehostamiseen sekä opetusministeriön ja sen alaisten yksiköiden roolijaon selkiyttämiseen. Ehdotukset poistaisivat aikuiskasvatukseen liittyvien asioiden jakaantumisen kahteen organisatoriseen linjaan. Varsinkin nykyisen ammattikasvatushallituksen käsiteltäviä asioita siirtyisi huomattavasti läänitasolle. Sen kautta lääninhallintoon muodostuisi koulutoimen hallinnon koko alueen nykyistä paremmin kattava piirihallinto. 